\title{
Mahshid Moshiri. Mille ans de poésie persane. Les poètes persanophones. A partir de l'apparition du persan jusqu'à présent
}

\section{Laetitia Nanquette (Bif)}

\section{(2) OpenEdition Journals}

Édition électronique

URL : http://journals.openedition.org/abstractairanica/40992

DOI : 10.4000/abstractairanica.40992

ISSN : 1961-960X

Éditeur :

CNRS (UMR 7528 Mondes iraniens et indiens), Éditions de l'IFRI

\section{Édition imprimée}

Date de publication : 1 décembre 2013

ISSN : 0240-8910

\section{Référence électronique}

Laetitia Nanquette (Bif), « Mahshid Moshiri. Mille ans de poésie persane. Les poètes persanophones. A partir de l'apparition du persan jusqu'à présent », Abstracta Iranica [En ligne], Volume 32-33 | 2013, document 440, mis en ligne le 01 juillet 2016, consulté le 02 octobre 2020. URL : http:// journals.openedition.org/abstractairanica/40992 ; DOI : https://doi.org/10.4000/abstractairanica. 40992

Ce document a été généré automatiquement le 2 octobre 2020.

Tous droits réservés 


\section{Mahshid Moshiri. Mille ans de poésie persane. Les poètes persanophones. A partir de l'apparition du persan jusqu'à présent}

Laetitia Nanquette (Bif)

\section{RÉFÉRENCE}

Mahshid Moshiri. Mille ans de poésie persane. Les poètes persanophones. A partir de l'apparition du persan jusqu'à présent. Paris, L'Harmattan, 2009, 238 p.

Cet ouvrage, à mi-chemin entre la recherche universitaire et la vulgarisation, se veut une introduction à la poésie persane pour un lectorat français. Son introduction distingue différentes périodes pour la poésie persane et offre quelques éléments de stylistique. Il se compose de 555 entrées organisées par ordre alphabétique, consacrées aux poètes persans et aux termes essentiels de la poésie persane, ce qui est malheureusement redondant avec l'introduction. Les entrées sur les poètes comportent quelques phrases sur leur biographie, leur œuvre, et, lorsque l'A. le considère possible et important, la traduction de quelques vers. Viennent ensuite des annexes sur l'histoire et la géographie de l'Iran. L'ensemble manque de cohérence et on imagine mal quel peut être son lectorat, dans la mesure où la recherche universitaire est pauvre et où le style est trop sec pour un lecteur qui voudrait s'initier à la poésie persane. 


\section{AUTEURS}

LAETITIA NANQUETTE (BIF)

Paris 